\title{
LETTER TO THE EDitoR New trends in assessment of mental disability in psychiatric reports - The use of International Classification of Functioning, Disability and Health (ICF)
}

\author{
Novas tendências na avaliação de incapacidade mental em \\ perícias psiquiátricas - Uso da Classificação Internacional \\ de Funcionalidade, Incapacidade e Saúde (CIF) \\ Eduardo Henrique Teixeira' \\ https://orcid.org/0000-0003-1376-5080 \\ Eduardo Santana Cordeiro \\ https://orcid.org/0000-0003-1621-951X \\ Cassia Maria Buchalla $a^{3}$ \\ https://orcid.org/0000-0001-5169-5533
}

\section{MR. EDITOR,}

The mental capacity, termed civil capacity in the context of forensic psychiatry, is the status that allows a person to acquire rights and contract obligations on his own without the need for a legal representative'.

Since the creation of the Statute of the Person with Disabilities in 2015 (Law 13.146/2015) several questions about the expert assessment of disability have been the focus of discussion. The statute deals with the rights and accessibility of persons with a long-term physical, mental, intellectual, or sensorial disability. It changed the Civil Code excluding the possibility of a person being considered totally incapable in Brazil. In addition, it brings a new possibility to the expert conclusion: Decision Making Support for individuals with slight limitations ${ }^{2,3}$.

All these changes are in line with world trends and advances in medicine, psychiatric treatments, diagnosis, and prognosis. Thus, in civil capacity assessments also, a modernization can be expected.

Since it is no longer possible simply to conclude that an individual is totally or partially incapacitated, changes and improvement of the expertise will be necessary to produce more elaborate and grounded conclusions. It is necessary to declare the disability, when present, but it should be comprehensively vetted with specific questions and with details on the level of the limitation.

In 2001, the WHO (World Health Organization) published the International Classification of Functioning, Disability and Health - ICF, currently in the $1^{\text {st }}$ edition. This classification defines functionality as a dynamic relationship between a person's health condition and the context conditions, that is, personal and environmental factors. This interaction is shown in a biopsychosocial model as one of the novelties of this classification. Environmental aspects include, but are not limited to, support, access to assistance, and public policy, both as barriers

1 Pontifícia Universidade Católica de Campinas (PUC-Campinas), Departamento de Psiquiatra da Faculdade de Medicina, São Paulo, SP, Brasil.

2 Universidade de São Paulo (USP), Faculdade de Saúde Pública; Grupo CIF Brasil, São Paulo, SP, Brasil.

3 Universidade de São Paulo (USP), Faculdade de Saúde Pública, Departamento de Epidemiologia, São Paulo, SP, Brasil. 
and as facilitators. The use of the ICF allows a more accurate and realistic assessment of the individual's situation ${ }^{4,5}$.

In the field of forensic psychiatry, the use of the ICF will allow the standardization of expert evaluations and result in a more grounded report Its use will not be restricted only to the assessment of civil capacity, since it may also involve evaluated of capacity of labor, in which case, it would be necessary to detail the degree of mental commitment and the functions the patient is limited in. Through a partnership with CRM-SP (Regional Medical Council of São Paulo State), it already being used by the Public Prosecutor's Office of São Paulo6.

Finally, for severely compromised individuals, as they can no longer be declared "totally incapable", the detailed description of the disability would be well characterized and will allow the judge to delimit the levels of curatorship, even if total. For those individuals in whom the limitation is minimal, a careful evaluation may also assist in the indication of Supported Decision Making, under the terms of the current Statute of the Person with Disabilities ${ }^{2,3}$.

\section{INDIVIDUAL CONTRIBUTIONS}

Eduardo Henrique Teixeira - Drafting and finalization of the manuscript.

Eduardo Santana Cordeiro - Finalization of the manuscript.

Cassia Maria Buchalla - Finalization of the manuscript.

\section{CONFLICTS OF INTEREST}

The authors report no conflicts of interest.

\section{REFERÊNCIAS}

1. Teixeira EH, Barros DM. Perícia em Direito Civil. In: Teixeira EH, Barros DM (Orgs.). Manual de Perícias Psiquiátricas. 1a ed. Porto Alegre: Artmed; 2015. p. 37-67.

2. Brasil. Presidência da República. Casa Civil. Estatuto da Pessoa com Deficiência. Lei no 13.146, de 6 de julho de 2015. Disponível em: http://www.planalto.gov.br/ccivil_03/_ ato2015-2018/2015/lei/l13146.htm. Acesso em: 2 fev. 2019.

3. Abdalla-Filho E. Psychiatric evaluation of civil capacity with the new Brazilian statute of the person with disabilities. Rev Bras Psiquiatr. 2017;39(3):271-73.

4. World Health Organization (WHO). International Classification of Functioning, Disability and Health (ICF). Disponível em: http://www.who.int/classifications/icf/en/. Acesso em: 2 fev. 2019.

5. Araujo ES, Buchalla CM, Araujo ES, Buchalla CM. The use of the International Classification of Functioning, Disability and Health in health surveys: a reflexion on its limits and possibilities. Rev Bras Epidemiol. 2015:18(3):720-4.

6. São Paulo. Ministério Público. Quesitos para avaliação de incapacidade civil relativa ou absoluta.; 2017. Disponível em: http://www.mpsp.mp.br/portal/page/portal/cao_civel/ aa_ppdeficiencia/aa_ppd_autismo. Acesso em: 19 out. 2018. 